\title{
Effects of plant growth promoting rhizobacteria on maize in greenhouse and field trial
}

\author{
Mirjana Jarak $^{1 *}$, Nastasija Mrkovački ${ }^{2}$, Dragana Bjelić ${ }^{2}$, Dragana Jošić ${ }^{3}$, Timea Hajnal-Jafari ${ }^{1}$ \\ and Dragana Stamenov ${ }^{1}$ \\ ${ }^{1}$ Faculty of Agriculture, University of Novi Sad, Sq. D. Obradovića 8, Novi Sad, Serbia. \\ ${ }^{2}$ Institute of Field and Vegetable Crops, M. Gorkog 30, Novi Sad, Serbia. \\ ${ }^{3}$ Institute of Soil Science, Teodora Drajzera 7, Belgrade, Serbia.
}

Accepted 9 June, 2012

\begin{abstract}
The aim of the study was to investigate ability of Pseudomonas sp. Q4b, Bacillus sp. Q5a and Azotobacter chroococcum strain 8 to enrich a population of plant growth promoting rhizobacteria (PGPR) in rhizosphere and thus enhance maize growth (Zea mays L.). Experiments were carried out under greenhouse and field conditions, on a chernozem soil. In vitro screening for PGP properties showed significant difference between indole-3-acetic acid (IAA) and siderophores production and phosphosolubilization between Pseudomonas sp. Q4b and Bacillus sp. Q5a. Pseudomonas was estimated as a better producer of hydrogen cyanide (HCN) and siderophores than Bacillus. Bacterial treatments had a significant effect on the number of investigated microbial groups in rhizosphere, and maize growth and yield. Co-inoculation had an advantage compared to single inoculation, while in case of single strains, better effects were achieved in Pseudomonas and Azotobacter treatments. Inoculation increased the number of azotobacters (103.25\%), pseudomonads $(82.29 \%)$ and aerobic spore-forming bacteria $(52.65 \%)$ as well as height $(17.15 \%)$ and dry weight $(35.48 \%)$ of maize plants. The highest plant height was recorded in treatment with Pseudomonas and Bacillus. The highest dry weight and yield were recorded in the treatment with mixture of these three strains.
\end{abstract}

Key words: Maize, inoculation, plant growth promoting rhizobacteria, yield.

\section{INTRODUCTION}

Maize (Zea mays L.) is an important crop in temperate and semi-arid regions and one of the three major food staple crops for the world's population. In Serbia, maize is grown on about 1200000 ha of soils per year and results of yield testing on numerous locations show its high genetic potential (Jocković et al., 2010). Beside the genetic potential, achieving higher yields also require appropriate application of agro-technical measures, especially fertilization. After nitrogen $(N)$, phosphorus $(P)$ is the most limiting nutrient for crop yields, and is essential for maize growth and development (Wu et al., 2005). In order to increase the natural fertility of soils and develop new approaches to reduce the need for chemical fertilizers and pesticides the rhizosphere microorganisms

*Corresponding author. E-mail: mirjana@polj.uns.ac.rs. Tel/Fax: +381214853426. especially some rhizobacteria called plant growth promoting rhizobacteria (PGPR) are recognized as an important factor in sustainable agricultural production (Mrkovački and Bjelić, 2011).

PGPR may be important for plant nutrition by increasing $\mathrm{N}$ and $\mathrm{P}$ uptake by plants, and playing a significant role in the biofertilization of crops (Cakmakci et al., 2005). Maize stimulates different $\mathrm{N}_{2}$-fixers in its rhizosphere and the most abundant diazotrophs belonging to Enterobacteraceae and Azotobacteraceae families. Nu-merous studies have shown that inoculation of maize plants with PGPR strains caused significant in-crease in plant height, plant dry weight, root length and weight, yield, leaf area, and plant nutrient uptake of $\mathrm{N}, \mathrm{P}, \mathrm{K}, \mathrm{Fe}, \mathrm{Zn}, \mathrm{Mn}$ and $\mathrm{Cu}$ (Biari et al., 2008; Sachin, 2009; Yazdani et al., 2009).

Among the different bacterial genera that have been reported as PGPR (Azospirillum, Agrobacterium, Rhizobium, Enterobacter, Beijerinckia, Klebsiella, Xanthomonas, Phyllobacterium) (Lucy et al., 2004), 
Pseudomonas, Bacillus and Azotobacter are the most widely reported (Mrkovački and Milić, 2001; Joo et al., 2004; Poonguzhali et al., 2008; Đurić et al., 2011). Growth promotion and disease control by these bacteria are complex interrelated processes involving mechanisms that include synthesis of some phytohormones (auxins, cytokinins and gibberellins), production of siderophores, antibiotics, hydrogen cyanide $(\mathrm{HCN})$, and volatile compounds. Indirect mechanisms include phosphosolubilization, competition and induced systemic resistance (Lugtenberg et al., 2002).

Effectiveness of PGPR inoculations on plant growth enhancement and crop yields depends upon its ability to survive and multiply in soils and is influenced by many abiotic and biotic factors including texture, $\mathrm{pH}$, temperature, moisture content, soil type, soil amendment, nutritional status of the plant, plant species, plant age, microbial competition and predation (Van Veen et al., 1997; Marschner et al., 2004).

The aim of this study was to examine the effect of maize seed inoculation with Pseudomonas sp. Q4b and Bacillus sp. Q5a strains mixed with well known Azotobacter biofertilizer strain, applied in single or in coinoculation, on microbial population in rhizosphere and maize growth and yield. In addition, Pseudomonas sp. Q4b and Bacillus sp. Q5a strains were tested for their plant growth-promoting properties.

\section{MATERIALS AND METHODS}

\section{Bacterial strains}

PGPR were isolated from maize rhizosphere growing on poor pseudogley soil in central Serbia (Progoreoci, Aranđelovac). Selection of isolates was performed on the basis of the PGPR traits. Identification of selected isolates (Q4b as Pseudomonas sp. and Q5a as Bacillus sp.) were done using biochemical analysis and 16S rDNA partial sequences.

Bacterial isolates - Pseudomonas sp. Q4b and Bacillus sp. Q5a were grown on yeast manitol agar (YMA) supplemented with $6 \%$ $\mathrm{NaCl}$ for salt tolerance test or nutrient agar (NA) medium for various $\mathrm{pH}$ (from 4.5 to 9.5) adjusted with $1 \mathrm{M} \mathrm{HCl}$ or $1 \mathrm{M} \mathrm{NaOH}$ for $\mathrm{pH}$ tolerance.

\section{In vitro screening for plant growth-promoting properties}

\section{Phosphate solubilization}

Spot inoculations on Pikovskaya agar with $0.5 \%$ tricalcium phosphate $\left[\mathrm{Ca}_{3}\left(\mathrm{PO}_{4}\right)_{2}\right]$ were applied for solubilization assay (Pikovskaya, 1948). Appearing of clear zones were in positive corelation with phosphate solubilizing ability. Diameters of clear zones around the colonies after 5 days of incubation at $28^{\circ} \mathrm{C}$ were measured.

\section{Siderophores production}

Schwyn and Neilands (1987) chrome azurol S (CAS) assay was used for estimation of siderophore production. For CAS assay in solid medium, plates were spot inoculated with $10 \mu \mathrm{l}$ of $\sim 5 \times 10^{6} \mathrm{CFU}$
$\mathrm{mL}^{-1}$ on the CAS medium supplemented with 1/10 Nutrient Agar. The intensity of siderophores production was measured by zone of color change (green-blue to orange) after 5 days of incubation at $28^{\circ} \mathrm{C}$.

\section{Hydrocyanic acid $(\mathrm{HCN})$ production}

HCN production was tested on King B medium supplemented with glicine (4.4 $\mathrm{g} \mathrm{L}^{-1}$ ) (Ayyadurai et al., 2007). Filter papers were impregnated with $0.5 \%$ picric acid and $2 \%$ sodium carbonate, placed on the lid of inverted plates and sealed with parafilm. Inverted plates were incubated during 4 days at $28^{\circ} \mathrm{C}$ and production of cyanide was detected by discoloration of yellow filter paper to orange or brown.

\section{Indole acetic acid (IAA) production}

For quantitative analysis of IAA production, a $10 \mu \mathrm{l}$ of bacterial suspension (standardized to $O D_{600}$ of 0.625 ) were inoculated in liquid NA medium supplemented without and with $5 \mathrm{mM}$ of tryptophan (Glickman and Dessaux, 1995) and incubated 36h at standard temperature. Salkowski reagent (2\% $0.5 \mathrm{M}$ ferric chloride in $35 \%$ perchloric acid) was mixed with the supernatant $(2: 1 \mathrm{v} / \mathrm{v})$ and intensity of developed color was measured at $530 \mathrm{~nm}$ for IAA production.

\section{Greenhouse experiment}

Experiment was carried out in pots under greenhouse conditions, using non-sterile chernozem soil. Soil chemical analyses were done before sowing. Ten seeds were sown at 4 to $5 \mathrm{~cm}$ depth of chernozem soil in each Mitscherlich pot, in three replications. The soil used had the following characteristics: $\mathrm{pH}$ (in $\mathrm{H}_{2} \mathrm{O}$ ) - 8.49; $\mathrm{CaCO}_{3}-5.04 \%$; humus content $2.05 \%$; available $\mathrm{P}$ and $\mathrm{K}$ contents -

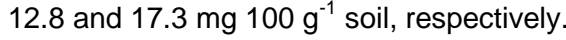

\section{Field experiment}

Experiment was conducted at the Rimski Šančevi Experiment Field of Institute of Field and Vegetable Crops in Novi Sad. The field is located on a calcareous chernozem on loess terrace. The chemical soil properties were: $\mathrm{pH}$ (in $\mathrm{H}_{2} \mathrm{O}$ ) - 7.43; $\mathrm{CaCO}_{3}-5.46 \%$; humus content $-2.47 \%$; available $\mathrm{P}$ and $\mathrm{K}$ contents -62.22 and $32.82 \mathrm{mg}$ $100 \mathrm{~g}^{-1}$ soil, respectively. The experimental design was a randomized, complete block with four replications. The length of the experimental unit was $5 \mathrm{~m}$, the width was $3 \mathrm{~m}$. The sowing was done in the spacing $75 \times 22 \mathrm{~cm}$.

\section{Bacterial treatments}

Seeds of maize hybrid NS 6010 developed at the Institute of Field and Vegetable Crops were inoculated with three bacterial strains: Azotobacter chroococcum strain 8 from the collection of the Institute of Field and Vegetable Crops in Novi Sad (NSCNFB, as registered in WDCM), Pseudomonas sp. Q4b and Bacillus sp. Q5a. Azotobacter was grown in Fiodor medium, Bacillus in the NA medium and Pseudomonas in King B medium, in liquid culture $\sim 6 \times$

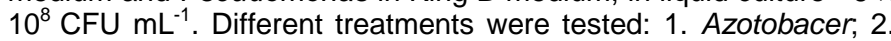
Bacillus; 3. Pseudomonas; 4. Azotobacter + Bacillus; 5. Azotobacter + Pseudomonas; 6. Bacillus + Pseudomonas; 7. Azotobacter + Bacillus + Pseudomonas (in a ratio 1:1:1). Maize seeds were soaked in $0.2 \% \mathrm{HgCl}_{2}$ and $70 \%$ alcohol for 3 to $5 \mathrm{~min}$ and washed with water several times. Seeds were treated with $1 \mathrm{ml}$ 
Table 1. Environmental adaptations and plant growth promoting properties of applied Pseudomonas sp. Q4b and Bacillus sp. Q5a strains.

\begin{tabular}{|c|c|c|c|}
\hline \multicolumn{2}{|l|}{ Isolates } & Pseudomonas sp. Q4b & Bacillus sp. Q5a \\
\hline \multicolumn{2}{|c|}{ Halo tolerance ability (6\% $\mathrm{NaCl}$ in $\mathrm{YMA})$} & $t^{a}$ & \pm \\
\hline \multicolumn{2}{|c|}{ Alkali tolerance ability (pH 9.5 of NA) } & + & \pm \\
\hline \multicolumn{2}{|c|}{ Acid tolerance ability ( $\mathrm{pH} 4.5$ of NA) } & + & \pm \\
\hline \multicolumn{2}{|c|}{ Phosphate solubilization - zones ( $\mathrm{mm} / 5$ day) } & $10.67 \pm 1.34^{b}$ & $4.6 \pm 0.87$ \\
\hline \multicolumn{2}{|c|}{ Siderophores production - zones ( $\mathrm{mm} / 5$ day) } & $7.67 \pm 0.44$ & $4.8 \pm 0.12$ \\
\hline \multicolumn{2}{|l|}{ HCN production } & + & \pm \\
\hline IAA production $\left(\mu \mathrm{g} \mathrm{mL}^{-1}\right)$ & $\begin{array}{l}\text { NB without tripthophane supplemented } \\
\text { NB supplemented with } 5 \mathrm{mM} \text { tripthophane }\end{array}$ & $\begin{array}{l}7.92 \pm 0.17 \\
20.97 \pm 0.25\end{array}$ & $\begin{array}{l}0.88 \pm 014 \\
7.75 \pm 0.36\end{array}$ \\
\hline
\end{tabular}

a,$(+)$ bacterial growth; ( \pm ) poor bacterial growth; (-) no growth; ${ }^{\mathrm{b}}$, means and standard deviations values.

of inoculum. No treated seeds were designed as control.

\section{Effect on microbial population in maize rhizosphere}

The rhizosphere soil for microbiological analysis was sampled at the three- and six-leaf stage of maize. The total microbial count was done in soil agar (dilution $10^{7}$ ), the fungi in potato dextrose agar (dilution $10^{4}$ ), the pseudomonads in King B medium (dilution $10^{6}$ ), the aerobic spore-forming bacteria and non-spore forming bacteria in NA medium (dilution $10^{6}$ ), and the number of azotobacters in Fiodorov medium (dilution $10^{2}$ ) (Jarak and Đurić, 2004). All microbiological analyses were performed in three replications and the average number of microorganisms was calculated at $1.0 \mathrm{~g}$ absolutely dry soil.

\section{Effect on maize growth}

Maize plants were harvested at the three- and six-leaf stage and carefully separated from soil. Plant height $\left(\mathrm{cm} \mathrm{plant}^{-1}\right)$ and dry weight of plant ( $\mathrm{g} \mathrm{plant}^{-1}$ ) of each plant were recorded and the average per plant was calculated. Dry weight was recorded after drying in an oven at $50^{\circ} \mathrm{C}$ to constant weight.

\section{Data analysis}

Data were analyzed by analysis of variance (ANOVA); LSD and Duncan test were used to separate treatment means when there was a significant difference at the $\mathrm{P}<0.05$ level. Time of sampling was considered a random effect and treatments was a fixed effect. All analyses were conducted using the statistical software package STATISTICA 10.0 (StatSoft Inc. USA) (Mead et al., 1996).

\section{RESULTS AND DISCUSSION}

\section{Plant growth promoting properties of Pseudomonas sp. Q4b and Bacillus sp. Q5a strains}

Soil properties have a strong impact on a range of processes influencing crop yield, including microbial diversity. According to Rengel and Marschner (2005), chemical changes in the rhizosphere result in altered abundance and composition of microbial communities. Adaptations of bacteria to different soil properties and a broad range of $\mathrm{pH}$ and salinity may lead to better competition and survivals. Investigated bacteria in our work expressed good potential for adaptation. Adaptations to high salt concentration and $\mathrm{pH}$ values ranged from 4.5 to 9.5, and plant growth promoting properties of Pseudomonas sp. Q4b and Bacillus sp. Q5a strains are shown in Table 1.

Investigated bacteria in our work expressed good potential for adaptation. Pseudomonas sp. strain Q4b showed better tolerance abilities to high (9.5) and low (4.5) $\mathrm{pH}$ value and to high salt concentration then Bacillus sp. Q5a strain.

PGPR use one or more mechanisms to improve the growth and health of plants and can be active simultaneously or independently at different stages of plant growth. Among these, phosphosolubilization, improvement of other plant nutrients uptake, and phytohormone production (indole-3-acetic acid) are some of the regulators that influence plant growth (Zaidi et al., 2009). Production of IAA in liquid nutrient medium without tripthophane added were observed for Pseudomonas sp. Q4b in the same range as for Bacillus sp. Q5b in the same medium supplemented with $5 \mathrm{mM}$ of tripthophane. Substantial amount of indole-3-acetic acid were produced by $Q 4 b$ strains in the presence of tripthophane $-20 \mu \mathrm{g}$ $\mathrm{mL}^{-1}$.

Large proportion of phosphorus in soil is insoluble and therefore unavailable to plants (Singh and Kapoor, 1994). Plant rhizospheric bacteria Bacillus and Pseudomonas are able to solubilize phosphates in vitro and most of them act as PGPR (Joo et al., 2004; Poonguzhali et al., 2008). Investigated strains $Q 4 b$ and $Q 5 a$ showed good phosphosolubilization ability -4.6 to $10.67 \mathrm{~mm}$ after 5 days of cultivation on Pikovskaya agar plates supplemented with calcium phosphate.

Rhizospheric bacteria act as biological agents through the production of antibiotics, lytic enzymes, hydrogen cyanide, and siderophores or through competition for 
Table 2. Effect of PGPR on total microbial number, number of azotobacters and pseudomonads in maize rhizosphere $\left(\mathrm{g}\right.$ soil $\left.{ }^{-1}\right)$.

\begin{tabular}{lccc}
\hline \multirow{2}{*}{ Treatment } & \multicolumn{3}{c}{ Investigated microbial groups } \\
\cline { 2 - 4 } & Total microbial number $\left(\mathbf{\times 1 \mathbf { 1 0 } ^ { \mathbf { 7 } } )}\right.$ & Azotobacters $\left(\mathbf{\times 1 \mathbf { 0 } ^ { \mathbf { 2 } } )}\right.$ & Pseudomonads $\left(\mathbf{\times 1 \mathbf { 0 } ^ { \mathbf { 6 } } )}\right.$ \\
\hline Azotobacter & 255.43 & $191.69^{*}$ & 79.43 \\
Bacillus & 358.81 & $183.63^{*}$ & 70.42 \\
Pseudomonas & 304.02 & 68.76 & $130.82^{*}$ \\
Azotobacter + Bacillus & 458.06 & $258.05^{*}$ & 110.23 \\
Azotobacter + Pseudomonas & $773.61^{*}$ & $244.11^{*}$ & $363.63^{*}$ \\
Bacillus + Pseudomonas & 455.71 & $254.41^{*}$ & $131.03^{*}$ \\
Azotobacter + Bacillus + Pseudomonas & 567.92 & $280.89^{*}$ & 105.04 \\
Average & 453.37 & $211.65^{*}$ & $141.51^{*}$ \\
Non inoculated control & 500.52 & 104.13 & 77.63 \\
Increase (\%) & -9.42 & +103.25 & +82.29 \\
LSD 5\% & 170.3 & 40.7 & 34.3 \\
\hline
\end{tabular}

${ }^{*} p<0.05$ (significant).

Table 3. Effect of PGPR on number of fungi, spore-forming and non-spore forming bacteria in maize rhizosphere ( $\mathrm{g}$ soil $\left.{ }^{-1}\right)$.

\begin{tabular}{lccc}
\hline \multirow{2}{*}{ Treatment } & \multicolumn{3}{c}{ Investigated microbial groups } \\
\cline { 2 - 4 } & Fungi $\left(\mathbf{\times 1 \mathbf { 1 } ^ { \mathbf { 4 } } )}\right.$ & Spore-forming bacteria $\left(\mathbf{\times 1 \mathbf { 1 0 } ^ { \mathbf { 6 } } )}\right.$ & Non-spore forming bacteria $\left(\mathbf{\times 1 \mathbf { 0 } ^ { 6 }}\right)$ \\
\hline Azotobacter & 27.12 & 192.93 & 324.75 \\
Bacillus & $56.78^{\star}$ & $657.63^{*}$ & 899.47 \\
Pseudomonas & $52.97^{*}$ & $642.97^{*}$ & 502.42 \\
Azotobacter + Bacillus & 47.60 & 200.58 & 952.77 \\
Azotobacter + Pseudomonas & 45.45 & 384.69 & $1314.45^{*}$ \\
Bacillus + Pseudomonas & 31.37 & 289.29 & 374.35 \\
Azotobacter + Bacillus + Pseudomonas & 35.73 & $761.35^{*}$ & 826.86 \\
Average & 42.43 & 447.06 & 742.15 \\
Non-inoculated control & 41.31 & 292.87 & 875.92 \\
Increase (\%) & +2.71 & +52.65 & -15.27 \\
LSD 5\% & 9.85 & 277.0 & 183.1 \\
\hline
\end{tabular}

${ }^{*} \mathrm{p}<0.05$ (significant).

nutrients and space. Biological control of plant pathogens and deleterious microbes can improve significantly plant health, as evidenced by increases in seedling emergence, vigor and yield (Antoun and Kloepper, 2001). Pseudomonas sp. Q4b was estimated as better producer of HCN and siderophores than Bacillus sp. Q5a strain and assumed to be better in promoting maize growth.

\section{Microbial population in maize rhizosphere}

Rhizosphere is a dynamic system controlled by the combined effects of soil properties, plants characteristics and the interactions of plant roots with microorganisms and the surrounding soil (Bowen and Rovira, 1999). High concentration of easily degradable substrates in root exudates leads to a proliferation of microorganisms in rhizosphere (Bais et al., 2006) and thus plant create its specific microflora that may have neutral, deleterious or beneficial effects on the plant. Greenhouse experiment was established on a chernozem soil that provides optimum conditions for microbiological activity (Đurić et al., 2008). Quantitative difference between the total number of microorganisms and their enzymatic activity in soil is a reliable indicator of its potential and effective fertility (Govedarica et al., 1992). Pot experiment showed a significant effect on the number of investigated microbial groups that varied depending on the applied strains (Tables 2 and 3 ).

Inoculation increased the number of azotobacters $(103.25 \%)$, pseudomonads (82.29\%) and aerobic sporeforming bacteria $(52.65 \%)$, while the total microbial number and the number of aerobic non-spore forming bacteria was decreased by 9.42 and $15.27 \%$, in relation 
Table 4. Effect of PGPR on maize growth.

\begin{tabular}{|c|c|c|}
\hline \multirow{2}{*}{ Treatment } & \multicolumn{2}{|c|}{ Tested growth parameters } \\
\hline & Plant height (cm plant $\left.{ }^{-1}\right)$ & Dry weight (g plant $\left.{ }^{-1}\right)$ \\
\hline Azotobacter & 27.85 & $0.42^{*}$ \\
\hline Bacillus & 27.91 & $0.37^{*}$ \\
\hline Pseudomonas & $28.74^{*}$ & $0.38^{*}$ \\
\hline Azotobacter + Bacillus & $28.30^{*}$ & $0.41^{*}$ \\
\hline Azotobacter + Pseudomonas & $28.48^{*}$ & $0.43^{*}$ \\
\hline Bacillus + Pseudomonas & $29.49^{*}$ & $0.45^{*}$ \\
\hline Azotobacter + Bacillus + Pseudomonas & 27.68 & $0.50^{*}$ \\
\hline Average & 28.35 & 0.42 \\
\hline Non-inoculated control & 24.20 & 0.31 \\
\hline Increase (\%) & +17.15 & +35.48 \\
\hline LSD 5\% & 3.71 & 0.02 \\
\hline
\end{tabular}

${ }^{*} p<0.05$ (significant).

to control. The best effects on the number of investigated microbial groups were achieved in the treatment with strains applied in mixture which caused a proliferation of total microbial number $\left(567.92 \times 10^{7}\right)$, number of azotobacters $\left(280.89 \times 10^{2}\right)$, pseudomonads $(105.04 \times$ $\left.10^{6}\right)$ and aerobic spore-forming bacteria $\left(105.04 \times 10^{6}\right)$. Some previous researches suggested that the presence of microorganisms in the maize rhizosphere varies and that total number of microorganisms and number of azotobacters increases in the course of growing season (Govedarica et al., 1999; Bjelić et al., 2010). BalaševićTubić et al. (2011) reported that abundance of microorganisms in the rhizosphere, as well as soybean yield using microbiological fertilizer was stimulated by plowing under crop residues. Picard et al. (2008) observed that PGPR were earlier stimulated in the rhizosphere of a hybrid maize than in those of its two parental lines and that each maize genotype stimulated the AMF (Arbuscular Mycorrhizal Fungi) population differently.

Azotobacter and Pseudomonas co-inoculation led to a significant increase in total microbial number $(773.61 \times$ $\left.10^{7}\right)$, number of azotobacters $\left(244.11 \times 10^{2}\right)$, pseudomonads $\left(363.63 \times 10^{6}\right)$ and aerobic non-spore forming bacteria $\left(1314.45 \times 10^{6}\right)$ compared to control. Jarak et al. (2005) showed that number of azotobacters in the first ten days decreases from $10^{8}$ to $10^{2}$ cells, but after twenty days increases to more than $10^{3}$ which suggest that this soil provides favorable conditions for bacteria that require a well-controlled water-air regime, enough easily degradable substances and neutral reaction.

The maximum number of investigated microorganisms was recorded when Azotobacter co-inoculated with Pseudomonas, subsequently with Bacillus, while the least effect was detected when Bacillus co-inoculated with Pseudomonas, regarding the effect of two strains together. Observed by individual strains best effects were obtained in the Pseudomonas treatment, superior in relation to Bacillus or Azotobacter treatment. Inoculation with Pseudomonas led to an increase in the number of pseudomonads $\left(130.82 \times 10^{6}\right)$, spore-forming bacteria $\left(642.97 \times 10^{6}\right)$ and fungi $\left(52.97 \times 10^{4}\right)$. Bacillus caused a decrease in the number of azotobacters, pseudomonads and total microbial number compared to control, while good effect was recorded on the number of sporeforming, non-spore forming bacteria and fungi. Treatment with Azotobacter significantly increased the number of azotobacters $\left(191.69 \times 10^{2}\right)$, while the effect on the other microbial groups was better when Azotobacter is combined with Bacillus or Pseudomonas and in treatment with all three strains. Plant growth promotion is crucial in early developmental stages such as germination and seedling growth (Gholami et al., 2009). Establishment of a significant number of PGPRs in rhizosphere and plant tissues leads to an increase in biomass (even grain production) in later developmental stages (Bashan et al., 2004).

\section{Maize growth}

The applied PGPR strains significantly affected the height and dry weight of maize plants (Table 4). Responses of greenhouse-grown maize to PGPR inoculation also depended on applied strains that had similar effects as on microbial population in maize rhizosphere.

Results reveal that mentioned growth parameters increased in PGPR treated plants over non-inoculated control and that increase was significant for most of strains. The highest plant height $\left(29.49 \mathrm{~cm}\right.$ plant $\left.{ }^{-1}\right)$ was recorded in treatment with Pseudomonas and Bacillus. The highest dry weight $\left(0.50 \mathrm{~g} \mathrm{plant}^{-1}\right)$ was recorded in the treatment with mixture of all three strains. In 


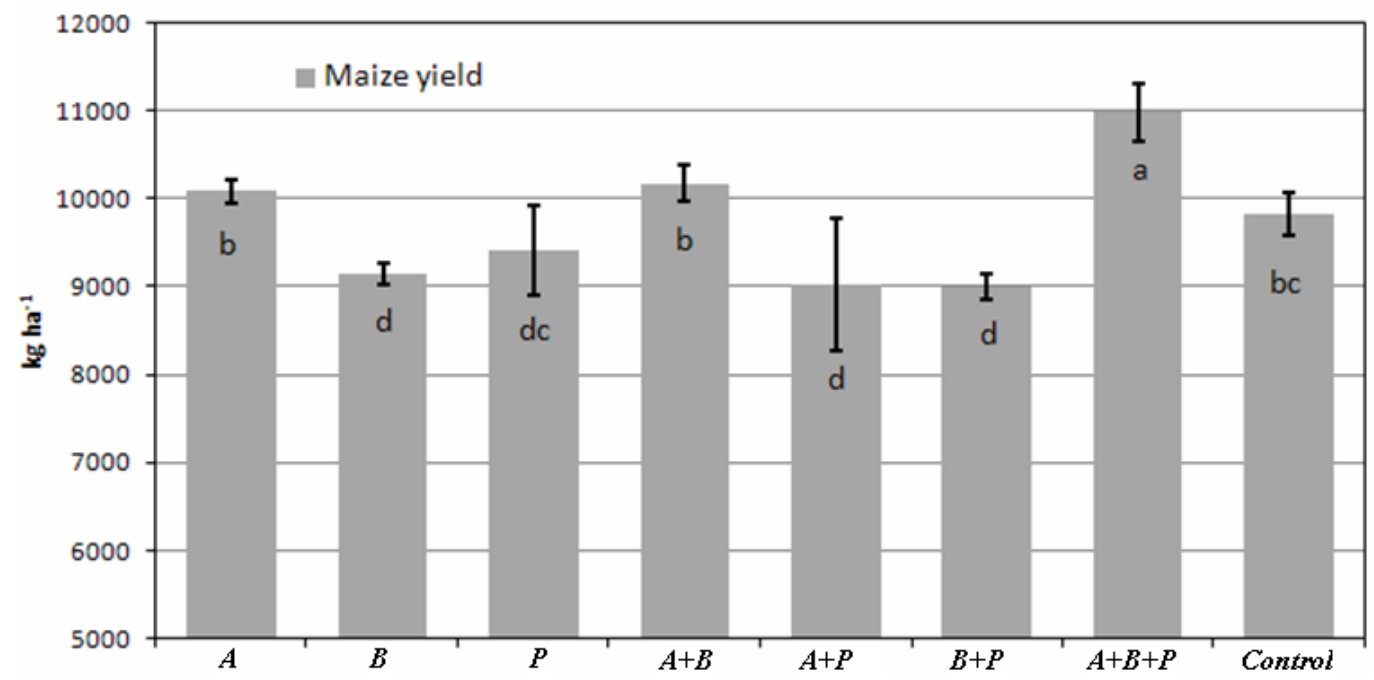

Figure 1. Effect of PGPR on maize yield (A: Azotobacter; B: Bacillus; P: Pseudomonas; $A+B$ : Azotobacter + Bacillus; A+P: Azotobacter + Pseudomonas; B+P: Bacillus + Pseudomonas; A+B+P: Azotobacter + Bacillus + Pseudomonas).

comparison to single strains, combination of two or all three strains showed better results. In case of single strains, the best effect on plant height $\left(28.74 \mathrm{~cm}_{\text {plant }}{ }^{-1}\right)$ was achieved in treatment with Pseudomonas and in treatment with Azotobacter for dry weight of plant $(0.42 \mathrm{~g}$ plant $\left.^{-1}\right)$. Similarly, Stajković et al. (2011) showed that Rhizobium co-inoculation with Pseudomonas or Bacillus strains improved shoot dry weight, nitrogen and phosphorus contents in bean plants, compared to inoculation with Rhizobiumalone, whereby Pseudomonas promoted bean growth and particularly $P$ uptake more efficiently than Bacillus. Cassan et al. (2009) showed that Azospirillum brasilense and Bradyrhizobium japonicum, inoculated singly or in combination, promote seed germination and early seedling growth in soybean and maize, while root and shoot dry weight for co-inoculation was higher than for control or single-inoculation treatments. These results are in agreement with our assumptions that Pseudomonas will be better in maize growth promotion. Considering all PGP parameters tested in this study, there were significant difference between IAA and siderophores production and phosphosolubilization between Pseudomonas sp. Q4b and Bacillus sp. Q5a strains. Greenhouse experiment confirmed growth promotion by representative Azotobacter strain, as well as the mixture of all three strains. However, greenhouse investigation showed little variations in bacterial effectiveness among Pseudomonas sp. Q4b and Bacillus sp. Q5a strains applied as single inoculum, as well as among all treatments, although the difference compared to non-inoculated control was significant. Based on the results, strains used in this study can be recommended as maize growth promoting rhizobacteria.

\section{Maize yield}

In the combined analysis of variance over treatments the effects of microbes showed significant $F$-test $(P<0.05)$ among selected treatments (Figure 1).

The higher maize yield was observed after application of three strains indicating that favorable soil condition was achieved. Though, control plot had higher yield possibly as a result of imbalance in microbial population in those treatments with single application that resulted with immobilization of some nutrients or suppression to other microorganisms. Also, our research indicates that application of Azotobacter could significantly increase maize yield compared with other two strains. The lowest yield was found at plots where both Pseudomonas sp. Q4b + Bacillus sp. Q5a were applied. Standard deviation represented with error bars showed higher variation in Azotobacter + Bacillus treatment that could be explained with uneven performance of applied strains across replication. Govedarica et al. (2001) found enrichment in investigated microbial population and yield increase for both tested hybrids and strains applied (single and coinoculation with $A$. chroococcum and Bacillus megatherium). Similar results - an increase of microbial count and maize yield in response to $A$. chroococcum, Azotobacter vinelandii, Azospirillum lipoferum, $B$. megatherium, Bacillus subtilis and Klebsiella planticola application - were obtained by Cvijanović et al. (2007).

\section{Conclusion}

This study confirmed plant growth ability of Pseudomonas sp. Q4b and Bacillus sp. Q5a strains. 
Investigated strains mixed with well known Azotobacter biofertilizer strain had significant impact on microbial population in rhizosphere and maize growth and yield, suggesting that can be applied as biofertilizers for improved maize production. The best results were achieved in the treatments with strains applied in mixture indicating that co-inoculation had an advantage over single inoculation. Further greenhouse and field studies should provide more definitive information about the movement and uptake of macroelements ( $\mathrm{N}$ and $\mathrm{P}$ ) to plants with the impacts of PGPR-based inoculants.

\section{ACKNOWLEDGEMENT}

Part of this study was conducted as part of the Project No. TR 31073: "Improvement of maize and sorghum production under stress conditions", which is supported by the Ministry of Education and Science of the Republic of Serbia.

\section{REFERENCES}

Antoun H, Kloepper JW (2001). Plant growth-promoting rhizobacteria (PGPR). In: Brenner S, Miller JH (eds) Encyclopedia of Genetics. Academic Press, New York. pp. 1477-1480.

Ayyadurai N, Ravindra Naik P, Sakthivel N (2007). Functional characterization of antagonistic fluorescent pseudomonas associated with rhizospheric soil of rice (Oryza sativa L.). J. Microbiol. Biotechnol. 17(6):919-927.

Bais P, Weir TL, Perry LG, Gilroy S, Vivanco JM (2006). The role of root exudates in rhizosphere interactions with plants and other organisms. Annu. Rev. Plant Biol. 57:233-266.

Balašević-Tubić S, Đukić V, Marinković J, Dozet G, Petrović K, Tatić M (2011). Importance of microbiological fertilizer used in soybean production: Agronomical and biological aspects. Afr. J. Microbiol. Res. 5(27):4909-4916.

Bashan Y, Holguin G, de-Bashan LE (2004). Azospirillum-plant relationships: physiological, molecular, agricultural and environmental advances. Can. J. Microbiol. 50(8):521-577.

Biari A, Gholami A, Rahmani HA (2008). Growth promotion and enhanced nutrient uptake of maize (Zea mays L.) by application of plant growth promoting rhizobacteria in arid region of Iran. J. Biol. Sci. 8(6):1015-1020.

Bjelić D, Mrkovački N, Jarak M, Jošić D, Đalović I (2010). Effect of PGPR on the early growth of maize and microbial abundance in rhizosphere. Contemp. Agric. 59(3-4):339-345.

Bowen GD, Rovira AD (1999). The rhizosphere and its management to improve plant growth. Adv. Agron. 66: 1-102.

Cakmakci R, Donmez D, Aydin A, Sahin F (2005). Growth promotion of plants by plant growth-promoting rhizobacteria under greenhouse and two different field soil conditions. Soil Biol. Biochem. 38:14821487.

Cassan F, Perrig D, Sgroy V, Masciarelli O, Penna C, Luna V (2009). Azospirillum brasilense Az39 and Bradyrhizobium japonicum E109, inoculated singly or in combination, promote seed germination and early seedling growth in corn (Zea mays L.) and soybean (Glycine $\max$ L.). Eur. J. Soil Biol. 45:28-35.

Cvijanović G, Milošević N, Jarak M (2007). The importance of diazotrophs as biofertilisers in the maize and soybean production. Genetika 39(3):395-404.

Đurić S, Jarak M, Hajnal-Jafari T (2008). Microbial activity in soil under the organic and conventional plant production. Contemp. Agric. 57(34):46-50.

Đurić S, Pavić A, Jarak M, Pavlović S, Starović M, Pivić R, Jošić D (2011). Selection of Indigenous fluorescent pseudomonad isolates from maize rhizospheric soil in Vojvodina as possible PGPR. Rom. Biotechnol. Lett. 16(5):6580-6590.

Gholami A, Shahsavani S, Nezarat S (2009). The effect of plant growth promoting rhizobacteria (PGPR) on germination, seedling growth and yield of maize. Int. J. Biol. Life Sci. 5:35-40.

Glickman E, Dessaux $Y$ (1995). A critical examination of the specificity of the salkowski reagent for indolic compounds produced by phytopathogenic bacteria. Appl. Environ. Microbiol. 61:793-796.

Govedarica M, Jarak M, Milošević N, Manojlović S (1992). The role of microorganisms in modern plant production. Field Veg. Crop Res. 20: 95-103.

Govedarica M, Jeličić Z, Jarak M, Milošević N, Stojnić N, Rašković D, Pavlović M (1999). Effect of diazotrophs and P-mobilisers on microbial activity under maize. Proc. Res. Pap. PKB-INI Agroekonomik 5(1):115-121.

Govedarica M, Jeličić Z, Stojnić N, Hajnal T, Milošev D (2001). Effectiveness of Azotobacter chroococcum and Bacillus megatherium in corn. Soil Plant 50:57-64.

Jarak M, Đurić S (2004). Laboratory Manual of Microbiology, Faculty of Agriculture, Novi Sad.

Jarak M, Hajnal T, Đurić S, Zurkić J (2005). Survival of rhizobia, azotobacter and actinomycetes in soil of different $\mathrm{pH}$ values. Anal. Sci. Pap. 29(1):41-49.

Jocković Đ, Stojaković M, Ivanović M, Bekavac G, Popov R, Đalović I (2010). NS maize hybrids - today and tomorrow. Field Veg. Crop Res. 47(1):325-333.

Joo GJ, Kim YM, Lee IJ, Song KS, Rhee IK (2004). Growth promotion of red pepper plug seedlings and the production of gibberellins by Bacillus cereus, Bacillus macroides and Bacillus pumilus. Biotechnol. Lett. 26:487-491.

Lucy M, Reed E, Glick BR (2004). Application of free living plant growthpromoting rhizobacteria. Antonie van Leeuwenhoek 86:1-25.

Lugtenberg BJ, Chin-A-Woeng TF, Bloemberg (2002). GV Microbeplant interactions: principles and mechanisms. Antonie van Leeuwenhoek 81:373-383.

Marschner P, Crowley D, Hong Yang C (2004). Development of specific rhizosphere bacterial communities in relation to plant species, nutrition and soil type. Plant Soil 261:199-208.

Mead R, Curnow NR, Hasted MA (1996). Statistical methods in agriculturae and experimental biology, Chapman and Hall, London, pp. 415.

Mrkovački N, Bjelić D (2011). Plant growth promoting rhizobacteria (PGPR) and their effect on maize. Field Veg. Crop Res. 48(2):305312.

Mrkovački N, Milić V (2001). Use of Azotobacter chroococcum as potentially useful in agricultural application. Anal. Microbiol. 51(2):145-158.

Picard C, Baruffa E, Bosco M (2008). Enrichment and diversity of plantprobiotic microorganisms in the rhizosphere of hybrid maize during four growth cycles. Soil Biol. Biochem. 40:106-115.

Pikovskaya RI (1948). Mobilization of phosphorus in soil in connection with vital activity of some microbial species. Microbiology 17:362-370.

Poonguzhali S, Madhaiyan M, Sa T (2008). Isolation and identification of phosphate solubilizing bacteria from Chinese cabbage and their effect on growth and phosphorus utilization of plants. J. Microbiol. Biotechnol. 18:773-777.

Rengel Z, Marschner P (2005). Nutrient availability and management in the rhizosphere: exploiting genotypic differences. New Phytol. 168:305-312.

Sachin DN (2009). Effect of Azotobacter chroococcum (PGPR) on the growth of Bamboo (Bambusa bamboo) and maize (Zea mays L.) plants. Biofrontiers 1:37-46.

Schwyn B, Neilands JB (1987). Universal chemical assay for detection and determination of siderophore. Anal. Biochem. 160:47-56.

Singh S, Kapoor K (1994). Solubilization of insoluble phosphates by bacteria isolated from different sources. Environ. Ecol. 12:51-55.

Stajković O, Delić D, Jošić D, Kuzmanović $Đ$, Rasulić N, KneževićVukčević J (2011). Improvement of common bean growth by coinoculation with Rhizobium and plant growth-promoting bacteria. Rom. Biotechnol. Lett. 16(1):5919-5926.

Van Veen JA, Leonard S, Van Overbeek LS, Van Elsas JD (1997). Fate and activity of microorganisms introduced into soil. Microbiol. Mol. 
Biol. Rev. 61:121-135.

Wu SC, Caob ZH, Lib ZG, Cheunga KC, Wonga MH (2005). Effects of biofertilizer containing $\mathrm{N}$-fixer, $\mathrm{P}$ and $\mathrm{K}$ solubilizers and $\mathrm{AM}$ fungi on maize growth: a greenhouse trial. Geoderma, 125:155-166.

Yazdani M, Bahmanyar AM, Pirdashti H, Esmaili AM (2009). Effect of phosphate solubilization microorganisms (PSM) and plant growth promoting rhizobacteria (PGPR) on yield and yield components of corn (Zea mays L.). World Acad. Sci. Eng. Technol. 49:90-92.
Zaidi A, Khan MS, Ahemad M, Oves M (2009). Plant growth promotion by phosphate solubilizing bacteria. Acta Microbiol. Immunol. Hung. 56:263-284. 